\title{
Combined oncolytic adenovirus carrying MnSOD and mK5 genes both regulated by survivin promoter has synergistic inhibitory effect on gastric cancer
}

\author{
Shanshan Liu ${ }^{1}$, JinQing $\mathrm{Hu}^{2}$, Jinfa $\mathrm{Gu}^{2}$, Aimin $\mathrm{Ni}^{2}$, Wenhao Tang ${ }^{3}$, Xinyuan Liu ${ }^{2}$ *
}

1 Laboratory of Cell Biology, Xin-yuan Institute of Medicine and Biotechnology, College of Life Science, Zhejiang Sci-Tech University, Hangzhou, 310018, China, 2 State Key Laboratory of Cell Biology, Center for Excellence in Molecular Cell Science, Chinese Academy of Sciences, Shanghai, 200031, China, 3 Department of General Surgery, Huadong Hospital, Fudan University, Shanghai, 200040, China

*xyliu@sibcb.ac.cn / wenhaotang1969@aliyun.com

\section{Abstract}

Gastric cancer (GC) is one of the major causes of cancer related mortality. The use of oncolytic virus for cancer gene-virotherapy is a new approach for the treatment of human cancers. In this study, a novel Survivin promoter driven recombinant oncolytic adenovirus carrying $m K 5$ or $M n S O D$ gene was constructed, which was modified after deletion of E1B gene. Human plasminogen Kringle 5 mutant $(m K 5)$ and manganese superoxide dismutase $(M n S O D)$ are both potential tumor suppressor genes. To construct Ad-Surp- $m K 5$ and Ad-Surp-MnSOD oncolytic adenovirus, we hypothesized that the combination of the two viruses would enhance the therapeutic efficacy of GC as compared to the virus alone. The results of the in vitro experiments revealed that the combination of adenovirus carrying 
$m K 5$ and $M n S O D$ gene exhibited stronger cytotoxicity to GC cell lines as compared to the virus alone, Additionally, the virus could selectively kill cancer cells and human somatic cells. Cell staining, flow cytometry and western blot analysis showed that the combination of two adenovirus containing therapeutic genes could promote the apoptosis of cancer cells. In vivo experiments further verified that Ad-Surp- $m K 5$ in combination with Ad-Surp-MnSOD exhibited significant inhibitory effect on the growth of GC tumor xenograft as compared to the virus alone, and no significant difference was observed in the body weight of treatment and the normal mice. In conclusion, the combination of our two newly constructed recombinant oncolytic adenovirus containing $m K 5$ or $M n S O D$ therapeutic genes could significantly inhibit gastric cancer growth by inducing apoptosis, suggestive of its potential for GC therapy.

Keywords Gastric cancer $\cdot \mathrm{mK} 5 \cdot \mathrm{MnSOD} \cdot$ Survivin $\cdot$ Adenovirus

\section{Introduction}

Gastric cancer (GC) is the fifth most prevalent cancer worldwide and the third leading cause of cancer related mortality [1]. GC is one of the most common malignant tumors of the digestive system. At present, surgery is considered as the only radical cure. The 5-year survival rate of early gastric cancer may reach $95 \%$, but due to late diagnosis, most of the patients are diagnosed at advanced stages [2]. Despite advances in surgical techniques, radiotherapy, chemotherapy and neoadjuvant therapy [3], GC still remains a serious global health burden [4]. Many cancers can be cured by surgery, yet most of the world's population does not have access to safe, affordable and timely cancer surgery [5]. 
Worldwide interest in oncolytic viruses (OVs), a powerful new oncology drug, has increased remarkably with the approval of the first OV (Talimogene Laherparepvec) by the US Food and Drug Administration [6]. However, after extensive research oncolytic virus therapy is limited in the treatment of solid tumors.We used a novel strategy called targeted gene-virotherapy of cancer (CTGVT) that combined the advantages of gene therapy and oncolytic virus therapy to produce a stronger anti-tumor effect than either gene or oncolytic virus therapy alone [7]. For example, ONYX-015 is an oncolytic adenovirus (Ad) with deletion of its viral protein E1B-55kDa gene. Due to the inability of the mutated protein to degrade P53, the selectivity of tumor replication is enhanced. The early gene E1B gene encoded by Ads mainly contains two kinds of polypeptides E1B-19kDa and E1B-55kDa. E1B-19kDa is a homologous of Bcl-2 which can prevent E1A-induced apoptosis by interfering with Bak, Bax interaction. By E1B-19 kDa protein induced inhibition of FAS mediated apoptosis and inhibition of apoptosis of cancer cells through other apoptotic pathways, Ad knockout E1B-19 kDa after virus replication in restricted in normal cells and cancer cells are not suppressed [8]. In the host,the E1B-55 kDa protein binds to P53 which consequently leads to the inhibition of the viral replication. Therefore, OV-knockout E1B-55 kDa can't replicate in the normal cells, but the virus replicates normally in tumor cells lacking P53 function and causes tumor cells dissolve. However, the oncolytic adenovirus produced simply by deleting viral genes is not selective enough to prevent unnecessary tissue damage. Recently, tumor-specific promoters have become the most popular tool for controlling the oncolytic adenoviruses that strictly target cancer cells [9]. Survivin, a member of the apoptosis-inhibiting protein family, is overexpressed in 
several types of cancers but is not expressed in differentiated normal tissues [10]. The results suggest that Survivin promoter is a specific promoter for a variety of cancers and may play a role in cancer gene therapy, and that Survivin promoter is more tumor-specific than CMV promoter in vivo [11].

The anti-angiogenic protein K5 (human plasminogen Kringle 5) forms the $m K 5$ mutation by mutation of 71 leucine residue to arginine [12]. Studies have shown that $m K 5$ and $\mathrm{K} 5$ can considerably inhibit the proliferation of human umbilical vein endothelial cells (HUVECs) and induce the apoptosis of vascular endothelial cells in vivo and in vitro. Additionally, $m K 5$ has a stronger effect on the induction of HUVECs apoptosis [13]. Previous studies have shown that OV-mediated $m K 5$ can inhibit the growth of colorectal cancer [14] and prostate cancer [15]. Cancer often involves changes in the growth and proliferation of cells. DNA damage and excessive production of reactive oxygen species (ROS) have also been reported to be responsible for the development of cancer [16]. Antioxidant protein containing manganese oxide dismutase (MnSOD) is one of the key enzymes for the scavenging of mitochondrial reactive oxygen species (ROS) [17], and is also a novel tumor suppressor protein [18]. Significant growth inhibition was observed in human esophageal squamous [19], PC-3 human prostate cancer [20, 21], MeWo melanoma [22], osteosarcoma [23], ovarian cancer [24, 25], MCF-7 breast cancer [26], colorectal cancer [27, 28], hepatocellular carcinoma [29], and pancreatic cancer cell lines [30]. Overexpression of $\mathrm{mK} 5$ and MnSOD cDNA by plasmid transfection or adenovirus transduction in various types of cancer triggers growth inhibition in vivo and in vitro. In this study, Survivin promoter was used to regulate the expression of 
oncolytic adenovirus E1A. The tumor targeting gene viruses Ad-Surp- $m K 5$ and Ad-Surp-MnSOD were constructed for the first time, carrying therapeutic genes $m K 5$ and $M n S O D$ respectively. Moreover, the combined application of two recombinant oncolytic adenoviruses in gastric cancer was studied for the first time. Under both in vivo and in vitro conditions, the combination of Ad-Surp- $m K 5$ and Ad-Surp-MnSOD was more effective in the inhibition of tumor growth than Ad-Surp- $m K 5$ or Ad-Surp-MnSOD alone. The combination of two recombinant adenoviruses promoted the apoptosis of tumor cells and exhibited no toxic effects on the normal human somatic cells.

\section{Materials and methods}

\section{Cells and culture}

The human gastric cancer cell lines (HGC-27, NCI-87, AGS). Human embryonic kidney cell line (HEK293), human normal lung epithelial cell (Beas-2B), human liver cell (QSG-7701), human colon epithelial cell (NCM-460), and other human cancer cells (HCC-827, HepG-2, Huh-7, A549, SW480, SW620, MDA-MB-231, HeLa, PANC-1, 22RV1, BxPC-3, DU-145, MCF-7, SKOV-3, LNCaP) were purchased from Shanghai Cell Library, Chinese Academy of Sciences (Shanghai, China).

The AGS, HCC-827, HepG-2, SW480, BxPC-3, MCF-7, SKOV-3 and LNCaP were cultured in RPMI-1640 medium, A549 in F-12K medium, MDA-MB-231 in L-15 medium, DU-145 in MEM medium, and other cell lines were cultured in DMEM complete medium. The media was supplemented with $10 \%$ fetal bovine serum (Gibco BRL,Grand Island, NY,USA), and all cell lines were incubated in moist air at $37^{\circ} \mathrm{C}$ containing $5 \% \mathrm{CO}_{2}$. 
Table 1. Sequences of primers

\begin{tabular}{ll}
\hline Primers & Sequences \\
\hline survivin & Forward:5'-ATGGCCCTGTCCTTCAGC-3' \\
& Reverse:5'-TCACTCCTTCCTTCTCAGCC-3' \\
& Forward:5'-AATTCCCTGGCATTATGCCC-3' \\
& Reverse:5'-TCGATGCTAGACGATCCAGA-3'
\end{tabular}

Adeasy system was used to recombine adenovirus in our laboratory. In this study, the vector of Ad5 virus, shuttle plasmid pShuttle, pCA13, and pCA13-survivin were used. The oncolytic adenovirus plasmid pShuttle-E1A- $\triangle \mathrm{E} 1 \mathrm{~B}$ with $\mathrm{E} 1 \mathrm{~B}(19 \mathrm{kDa}, 55 \mathrm{kDa})$ gene deleted by site directed mutation was previously obtained and preserved, and the $m K 5$ and MnSOD genes were amplified from pXYA05- $m K 5$ and pXYA05-MnSOD respectively by reverse transcription polymerase chain reaction (PCR). The target gene was cloned into pCA13 (by HindIIIXhoI double digestion) in a seamless cloning way to obtain pCA13-gene. The pCA13-Survivin, pCA13-mK5 and pCA13-MnSOD were amplified by PCR. The expression box containing the target gene was seamlessly cloned into the corresponding position of the modified shuttle plasmid pShuttle-E1A- $\triangle \mathrm{E} 1 \mathrm{~B}$ to construct pShuttle-Surp (XhoI) -E1A- $\triangle$ E1B-transgene (BglII). All plasmids were verified by restriction enzyme digestion, PCR and DNA sequence. HEK293 cells were transfected with the Effectene ${ }^{\circledR}$ Transfection Reagent Transfection kit. To amplify the recombinant adenovirus PCR was performed, and the PCR primer sequences and seamless clone primer sequences used in the study are listed in Table 1. 
MnSOD

E1B 55kDa

E1B 19kDa

CMV-Transgene-SV40

PloyA

Survivin fusion cloning

$m K 5$ fusion cloning

MnSOD fusion cloning
Forward:5'-ATGAAGCACAGCCTCCCCGA-3'

Reverse:5'-TTACTTTTTGCAAGCCATGT-3'

Forward:5'-CAAAGGTGGCACTTAGGC-3'

Reverse:5'-AGGAACAGCGGGTCAGTA-3'

Forward:5'-TACATCTGACCTCATGGAGG-3'

Reverse:5'-CTTGATGACCTTCTCTTGGA-3'

Forward:5'-AATTCCCTGGCATTATGCCC-3'

Reverse:5'-TCGATGCTAGACGATCCAGA-3'

Forward:5'-TGGTACCGCGGCCGCCTCGAGAATTCCCTGGCATTATGCCC

$-3^{\prime}$

Reverse:5'-CTTTCAAAGAACGCGCTCGAGTCGATGCTAGACGATAAGA$3^{\prime}$

Forward:5'-AGTCTTCGAGTCGACAAGCTTAATTCCCTGGCATTATGCCC

$-3^{\prime}$

Reverse:5'-TCGATGCTAGACGATCCAGAGTCAGCCAACTAAAAAGGCC

C-3'

Forward:5'-AGTCTTCGAGTCGACAAGCTTATGAAGCACAGCCTCCCCG

A-3'

Reverse:5'-TTACTTTTTGCAAGCCATGTGTCAGCCAACTAAAAAGACCC

$-3^{\prime}$

Abbreviations: MnSOD:manganese superoxide dismutase; $m K 5$ : mutated K5(the keingle5 of human plasminagen)

\section{Western Blot analysis}

When multiplicity of infection (MOI) of the recombinant oncolytic adenovirus was 5, GC cells were infected, and the cell lysates were treated and collected after $48 \mathrm{~h}$ of incubation. Bradford method was used to detect protein concentration. The samples were 
run on the $10 \%$ polyacrylamide gel electrophoresis, and the proteins were transferred to the polyvinylidene difluoride (PVDF) membrane which was subjected to blocking with 5\% skimmed milk powder at room temperature for 30 minutes. This was followed by the incubation of the membranes with primary antibodies at $4{ }^{\circ} \mathrm{C}$ for $3 \mathrm{~h}$. The primary antibodies used in the study were Adenovirus-2/5 E1A (1:10000), MnSOD (1:10000), Caspase-3 (1:10000), Caspase-9 (1:10000), Cleaved-PARP (1:10000) (purchased from Santa Cruz Biotechnology. CA. USA), Caspase-8 (1:1000), Bcl-2 (1:1000), Bax (1:1000), SOD2 (1:1000) (purchased from Cell signaling Technology, Beverly, USA), $\beta$-actin (1:100000) (purchased from ABclonal Technology, Shanghai, China), $m K 5$ (1:1000) (purchased from HUABio. Hangzhou, China). This was followed by incubation with the corresponding secondary antibodies for $1.5 \mathrm{~h}$ and finally the membranes were scanned for the protein of interest.

\section{Cell Counting Kit-8 assays}

The cells were cultured in 96 well plates at a density of 3000 cells/well for $6 \mathrm{~h}$. To each well $10 \mu \mathrm{L}$ of the recombinant adenovirus after treatment (Different MOI gradient). Afterwards, CCK-8 detection kit (Beyotime, Shanghai, China) was used to detect cell vitality. The cells were continuously cultured at $37^{\circ} \mathrm{C}$ for $4 \mathrm{~h}$, and the absorbance was measured at $450 \mathrm{~nm}$ by enzyme-linked immunosorbent assay.

\section{Flow Cytometry analysis}

The GC cells were cultured in 6-well plates and treated with recombinant oncolytic adenovirus for $48 \mathrm{~h}(\mathrm{MOI}=5)$. After different treatments, the cells were subjected to 
treatment with trypsin and collected. Around 100,000 cells were resuspend into $500 \mu \mathrm{L}$ binding buffer. The analysis was repeated three times according to the manufacturer's instructions of Annexin V-FITC/PI kit (BD ISRI Sorp, Franklin Lakes, USA).

\section{EdU Cell proliferation Kit}

The GC cells were cultured in 24-well plates were treated with various recombinant oncolytic adenovirus for $48 \mathrm{~h}(\mathrm{MOI}=5)$ and then subjected to EdU labeling according to the manufacturer's instructions for EdU cell proliferation detection kit (Sangon Biotech, Shanghai, China).

\section{Animal experiment}

All animal protocols were approved by the Institutional Animal Handling and Use Committee (Scheme No.: SIBCB-S581-1609-027-C1). The animal welfare and laboratory procedures were strictly carried out in accordance with the Guide to Laboratory Animal Regulations and Standards. Female BALB/c (4-5 weeks) were purchased from Shanghai Experimental Animal Center, Chinese Academy of Sciences (SLAC, Shanghai, China). These experiments were conducted in specific pathogen free (SPF) level laboratory, Shanghai Institute for Biological Sciences, Chinese Academy of Sciences. The HGC-27 cells $\left(1 \times 10^{6}\right)$ were injected subcutaneously into nude mice to establish the tumor xenograft model. When the tumors were $80-100 \mathrm{~mm}^{3}$, the nude mice were divided into 5 groups with five mice in each group. The mice were injected with different recombinant oncolytic adenovirus $\left(1 \times 10^{8} \mathrm{PFU} / \mathrm{mouse}\right)$ or PBS every other day for three consecutive times. Tumor Length and Width was measured every other day after injection to calculate tumor volume: 
Volume $=\left(\right.$ Width $^{2} \times$ Length $) / 2$. Finally, tumors were harvested for analysis and the nick terminal labeling of dUTP biotin mediated by terminal deoxynucleotide transferase was performed.

\section{TUNEL assay}

The tumor tissues were fixed with $4 \%$ polymethanol for $6 \mathrm{~h}$ and subsequently dehydrated with $30 \%$ sucrose. The $6 \mu \mathrm{m}$ tissue sections were analysed by using apoptosis detection kit (red fluorescence, Beyotime). The procedure was carried out according to the manufacturer's instructions. The specimens were incubated with TUNEL at $37^{\circ} \mathrm{Cfor} 60 \mathrm{~min}$ and subjected to staining with 4',6-diamidino-2-phenylindole (DAPI) at room temperature for $30 \mathrm{~min}$. The specimens were sealed with anti-fluorescence quenching solution and observed under a fluorescence microscope.

\section{Statistical analysis}

The experiments were performed in triplicate and the values are presented as mean \pm SD. Student's t-test or one-way analysis of variance using were used for statistical analysis with the help of Prism GraphPad 8 software. ${ }^{*} \mathrm{P}<0.05,{ }^{*} \mathrm{P}<0.01$ and $* * * \mathrm{P}<0.001$ were taken as the measure the statistically significant differences. 


\section{Construction and Characterization of oncolytic adenovirus}

To identify the oncolytic adenovirus we had constructed, the corresponding PCR primers were designed and determined its location (Fig 1 A). The target gene was identified by PCR, $m K 5$-F primers and $m K 5$-R primers were used to identify $m K 5$ gene (Fig $1 \mathrm{~B}$, channel 4), $M n S O D$-F and $M n S O D$-R primers were used to identify $M n S O D$ gene (Fig 1 B, channel 6), Surp-F and Surp-R primers were used to identify Survivin genes (Fig 1B, channel 2), wild-type primers wild-F and wild-R were used to identify wild-type oncolytic adenovirus (Fig 1 B, channels 1, 3 and 5). The gel electrophoresis results showed that the structure of our recombinant oncolytic adenovirus was reasonable. The constructed oncolytic adenovirus was used to infect HGC-27 cells and the protein expression of $m K 5$ and $M n S O D$ were examined by western blot (Fig $1 \mathrm{C}$ ), which indicated that the constructed oncolytic adenoviruses could be expressed in gastric cancer cells.

\section{Selective killing effect of recombinant oncolytic adenovirus on gastric cancer cells in vitro}

To detect the killing effect of oncolytic adenovirus in vitro, we used Ad-Surp-empty, Ad-Surp- $m K 5$, Ad-Surp-MnSOD, Ad-Surp- $m K 5$ and Ad-Surp-MnSOD in combination with gradient MOI to infect GC cell lines HGC-27, NCI-87, AGS and human normal cells, human lung epithelial cell Beas-2B, human liver cell QSG-7701, human colon epithelial cell NCM-460 and CCK-8 assayed was used to detect their cell viability for 4 consecutive 
days. The cell viability of cancer cells treated with various oncolytic adenoviruses decreased significantly (Fig 2 A-F), while the cell activity of all kinds of normal human cells did not decrease significantly. The survival rate of cells at 72 and $96 \mathrm{~h}$ was above $80 \%$, indicating that the newly constructed oncolytic adenoviruses had certain selectivity in killing the cells (Fig 2 G-I ). At the same time, combination of Ad-Surp-mK5/MnSOD had the strongest killing effect, and the one with significant effect was observed on HGC-27 cells. The proliferation of HGC-27 cells was analyzed by EdU assay and same result was obtained (Fig 3).

\section{Apoptosis induced by recombinant oncolytic adenovirus in}

\section{gastric cancer cells}

Next, the recombinant oncolytic adenovirus induced cell death through apoptosis was analysed. We first detected the morphological changes of apoptosis in HGC-27 and QSG-7701 using Hoechst method. The results of the Hoechst 33342 fluorescent staining showed that the apoptotic rate of HGC-27 cells was higher under Ad-Surp-mK5/MnSOD (1:1) combination as compared to Ad-Surp- $m K 5$ or Ad-Surp-MnSOD treatments alone ( Fig 4 A-E) . QSG-7701 cells treated in the same way showed no significant difference in cell morphology compared with the control group (Fig 4 F-J). The apoptotic characteristics were reduced cell volume, condensed nucleoplasm, degradation of the nucleus into fragments and formation of apoptotic bodies. Similarly, flow cytometry analyzer was used to detect the apoptosis of HGC-27 cells (Fig 4L). Ad-Surp-Empty, Ad-Surp-mK5, Ad-Surp-MnSOD, Ad-Surp- $m K 5 / M n S O D$ (1:1) combined application was used to infect 
cells for $48(\mathrm{MOI}=5)$ hours, and the results showed that the apoptosis of cells in the newly constructed virus combined application group was significantly higher than that in the other groups.

The endogenous mitochondrial apoptotic pathway is the main pathway of mammalian programmed cell death. The oncolytic viruses mainly activate the caspase-dependent apoptosis signaling pathway. Western blotting assay was used to examine the apoptosis related proteins. The results showed that Ad-Surp-mK5/MnSOD (1:1) combination increased expression of Bax and cleaved-PARP while as the expression of PARP, caspase-3, caspase-9, caspase- 8 and Bcl-2 decreased considerably (Fig 5). The effects of Ad-Surp- $m K 5 / M n S O D$ (1:1) combination on the apoptosis related proteins were comparatively more significant than Ad-Surp- $m K 5$ or Ad-Surp-MnSOD treatments alone. These results indicate that the Ad-Surp-mK5/MnSOD (1:1) combination activates the caspase-induced cell signaling pathway in gastric cancer cells more than the other treatment groups and eventually promotes cell apoptosis.

\section{Antitumor effect of a newly constructed oncolytic adenovirus} Ad-Surp-mK5/MnSOD combination in vivo

To verify the antitumor activity of the newly constructed oncolytic adenovirus against gastric cancer in nude mice. We established a mouse model of gastric cancer xenotransplantation. The tumor measurement method, drug administration method and final treatment effect on the mice are shown in Fig 6A-B. Compared to the recombinant oncolytic adenovirus alone treatment group and the PBS group, the anti-tumor effect of 
Ad-Surp- $m K 5 / M n S O D$ combination group was significantly enhanced. Additionally, similar therapeutic effect was observed on the tumor growth (Fig 6 C), showing that the tumor volume in the Ad-Surp-mK5/MnSOD combination group decreased by $70 \%$ compared to the PBS group, and the efficacy was almost double that of the Ad-Surp-mK5 or Ad-Surp-MnSOD alone groups. The body weight of the experimental mice was measured during the experiment (Fig 6 D), there was no significant difference in body weight between the experimental mice in each group and the normal tumor-free nude mice. After tumor resection, the body weight and tumor mass of mice in each group were compared respectively (Fig 6 E-F). There was no significant difference in the body weight of each experimental mouse. However, in the tumor mass analysis of each group, the tumor mass of the virus combination group was significantly lower than those of the other treatment groups. When cells enter apoptosis, DNA ladders are generated by activation of some endonuclease, the exposed $3^{\prime}-\mathrm{OH}$ is labeled by dUTP catalyzed by terminal deoxynucleic acid transferase (TdT). To further verify the apoptotic status of oncolytic adenovirus infected tumors, the tissue immunofluorescence test was performed (Fig 7). The results showed that the Ad-Surp- $m K 5 / M n S O D$ combination treatment group significantly inhibited the tumor growth and induced a higher level of apoptosis as compared to other groups.

\section{Discussion}

The present study employed a novel strategy called CTGVT [31], to design a dual-regulatory oncolytic adenovirus vector, Ad-Surp-E1A- $\triangle \mathrm{E} 1 \mathrm{~B}$, that can replicate 
normally and cause tumor cell lysis in survivin-positive GC cells that lack P53 function

[32]. Our results indicate that mutant K5 and a novel tumor suppressor gene $M n S O D$ can

inhibit tumor growth by inducing tumor cell apoptosis. Ad-Surp- $m K 5$ in combination with

Ad-Surp-MnSOD (ratio: 1:1) can significantly inhibit the tumor growth in HGC-27

xenograft tumors, and the inhibition effect is more severe than that of the other two

recombinant oncolytic adenoviruses alone. These findings suggest that the combined use of

Ad-Surp-mK5 and Ad-Surp-MnSOD has great potential in the treatment of GC. Li et al.

showed that $m K 5$ can induce apoptosis of endothelial cells both in vivo and in vitro, and is

a more effective anti-angiogenic drug than K5 [13]. At the same time, in mature

endothelial cells, ROS is an important mediator of different signaling pathways related to

angiogenesis and cell metabolism, regulation of cell proliferation, migration and gene

plays a key role in the promotion of tumor angiogenesis, however, the molecular

mechanism underlying the regulation of VEGF expression under hypoxia remains unclear.

$\mathrm{Xu}$ et al. found that induction of VEGF in hypoxic HepG2 cells was ROS-dependent [34].

Studies have shown that ROS-mediated signals play a key role in the regulation of

transcription during hypoxia, and it has been reported that ROS-dependent mechanisms

induce VEGF to enter cancer cells under hypoxia conditions. Existing ROS scavengers can

reduce the expression of VEGF [35], while MnSOD is the main antioxidant in 
gene.

In the present study, we constructed two novel survivin-regulated, dual-targeted oncolytic adenovirus Ad-Surp-mK5/MnSOD, which carries the gene $m K 5$ or MnSOD. Our current data revealed that the anti-tumor efficacy of Ad-Surp-mK5 and Ad-Surp-MnSOD (1:1) combination in the treatment of gastric cancer is significantly better than that of Ad-Surp- $m K 5$ and Ad-Surp-MnSOD alone. It was further demonstrated that compared to the recombinant adenovirus alone, the combination of the virus induced apoptosis of gastric cancer cells specifically and the expression of caspase was stronger. Additionally, no toxicity was found in human lung epithelial cells, human liver cells and human colon cells in the in vitro as revealed by CCK- 8 assay. Above data show that our new construct is a potential candidate for experimental GC anticancer drug, Using CTGVT strategy to ensure the safety of viral vector we put the virus E1B knockout Ad5 as the initial viral vector, but simply deleted the viral gene does not stop unnecessary tissue damage, tumor selectivity can be enhanced by the placement of a tumor-specific promoter that is transcribed via mRNA upstream of a critical viral gene (E1A), so we used a novel Survivin promoter. [37]. Survivin promoter regulation of E1A gene makes up for the lack of selectivity of OVs vector. Adenovirus with anticancer therapy gene after recombination proliferates and replicates in gastric cancer cells, triggering the release of progeny virus and which subsequently infect and eventually destroy and kill the cancer cells. Chen et al. reported that when a system-managed suicide gene is driven by a Survivin promoter, systemic toxicity may be significantly reduced [38]. Meanwhile, Survivin promoters have been shown to induce transgenic overexpression in cancer [11]. 
Oncolytic therapy is another form of immune stimulation that works through the

patient's own immune system to combat tumor growth and facilitate tumor removal [39].

Although our novel survivin-regulated, dual-targeted OVs have achieved powerful

to be further addressed. The antiproliferative effects of Ad-Surp- $m K 5 / M n S O D$ against the

GC cells still remains low. Although they carry therapeutic genes $m K 5$ or/and $M n S O D$ and

soluble tumor recombinant adenovirus effectively inhibit the growth of nude mice tumors, effects through the combination of other conventional therapies.

In conclusion, OV successfully constructed by CTGVT strategies, through Survivin promoter regulation targeting tumor adenovirus vector which makes the recombinant adenovirus in GC cells more specific. It can effectively mediated $m K 5$ or $M n S O D$ gene expression maximizing the role of dissolving the tumor and inhibiting the tumor growth while minimizing side effects on normal tissues. Therefore, it has a wider application and may prove to be an important candidate for the treatment of GC.

\section{Acknowledgement}




\section{Reference}

1. Smyth EC, Nilsson M, Grabsch HI, van Grieken NCT, Lordick F. Gastric cancer. The Lancet 2020; 396 (10251): 635-648.

2. Song Z, Wu Y, Yang J, Yang D, Fang X. Progress in the treatment of advanced gastric ca-ncer. Tumour Biol 2017; 39 (7) :1010428317714626.

3. Tan Z. Recent Advances in the Surgical Treatment of Advanced Gastric Cancer: A Review. Med Sci Monit 2019; 25:3537-3541.

4. Smyth EC, Moehler M. Late-line treatment in metastatic gastric cancer: today and tomorrow. Ther Adv Med Oncol 2019; 11:1758835919867522.

5. Surgery NGHRUG. Quality and outcomes in global cancer surgery: protocol for a multicent-re, international, prospective cohort study (GlobalSurg 3). BMJ Open 2019; 9(5): $\mathrm{e} 026646$.

6. Fukuhara H, Ino Y, Todo T. Oncolytic virus therapy: A new era of cancer treatment at dawn. Cancer Sci 2016; 107(10):1373-1379.

7. Zheng M, Huang J, Tong A, Yang H. Oncolytic Viruses for Cancer Therapy: Barriers and Recent Advances. Mol Ther Oncolytics 2019; 15:234-247.

8. Goradel NH, Mohajel N, Malekshahi ZV, et al. Oncolytic adenovirus: A tool for cancer therapy in combination with other therapeutic approaches. J C-ell Physiol 2019; 234 (6): 8636-8646.

9. Abudoureyimu M, Lai Y, Tian C, Wang T, Wang R, Chu X. Oncolytic Adenovirus-A Nova for Gene-Targeted Oncolytic Viral Therapy in HCC. Front Oncol 2019; 9:1182. 
10. Lin KY, Cheng SM, Tsai SL, Tsai JY, Lin CH, Cheung CH. Delivery of a survivin promoter-driven antisense survivin-expressing plasmid DNA as a cancer therapeutic: a proof-of-concept study. Onco Targets Ther 2016; 9:2601-2613.

11. Chen JS, Liu JC, Shen L, Rau KM, Kuo HP, Li YM, et al. Cancer-specific activation of the survivin promoter and its potential use in gene therapy. Cancer Gene Ther 2004; 11(11):740-747.

12. Chang Y, Mochalkin I, McCance SG, Cheng B, Tulinsky A, Castellino FJ. Structure and ligand binding determinants of the recombinant kringle 5 domain of human plasminogen. Biochemistry 1998; 37 (10): 3258-3271.

13. Li C, Li L, Cheng R, Dai Z, Li C, Yao Y, et al. Acidic/neutral amino acid residues subst-itution in $\mathrm{NH} 2$ terminal of plasminogen kringle 5 exerts enhanced effects on corneal neovascularization. Cornea 2013; 32 (5) :680-688.

14. Fan JK, Xiao T, Gu JF, Wei N, He LF, Ding M, et al. Increased suppression of oncolytic adenovirus carrying mutant k5 on colorectal tumor. Biochem Biophys Res Commun 2008; 374(2): 198-203.

15. Hao J, Xie W, Li H, Li R. Prostate Cancer-Specific of DD3-driven Oncolytic Virus-harboring mK5 Gene. Open Med (Wars) 2019; 14:1-9.

16. Borrelli A, Schiattarella A, Bonelli P, Tuccillo FM, Buonaguro FM, Mancini A. The functional role of MnSOD as a biomarker of human diseases and therapeutic potential of a new isoform of a human recombinant MnSOD. Biomed Res Int 2014; 2014:476789. 
17. Sun G, Wang Y, Hu W, Li C. Effects of manganese superoxide dismutase (MnSOD) expression on regulation of esophageal cancer cell growth and apoptosis in vitro and in nude mice. Tumour Biol 2013; 34 (3): 1409-1419.

18. Zhang Y SB, Oberley LW. Enzymatic activity is necessary for the tumor-suppressive effects of MnSOD. Antioxid Redox Signal 2006.

19. Fan JJ, Hsu WH, Hung HH, Zhang WJ, Lee YA, Chen KC, et al. Reduction in MnSOD promotes the migration and invasion of squamous carcinoma cells. Int J Oncol 2019; 54(5):1639-1650.

20. Li X, Shen M, Cai H, Liu K, Liu Y, Huang Z, et al. Association between manganese superoxide dismutase (MnSOD) polymorphism and prostate cancer susceptibility: a metaanalysis. Int J Biol Markers 2016; 31 (4): e422-e430.

21. Sarsour EH, Kalen AL, Goswami PC. Manganese superoxide dismutase regulates a redox cycle within the cell cycle. Antioxid Redox Signal 2014; 20 (10): 1618-1627.

22. Torrens-Mas M, Cordani M, Mullappilly N, Pacchiana R, Riganti C, Palmieri M, et al. Mutant p53 induces SIRT3/MnSOD axis to moderate ROS production in melanoma cells. Arch Biochem Biophys 2020; 679:108219.

23. Sun W, Wang B, Qu XL, Zheng BQ, Huang WD, Sun ZW, et al. Metabolism of Reactive Oxygen Species in Osteosarcoma and Potential Treatment Applications. Cells 2019; 9 (1).

24. Bonetta R. Potential Therapeutic Applications of MnSODs and SOD-Mimetics. Chemistry 2018; 24 (20): 5032-5041. 
25. Wang S, Shu J, Chen L, Chen X, Zhao J, Li S, et al. Synergistic suppression effect on tumor growth of ovarian cancer by combining cisplatin with a manganese superoxide dismutase-armed oncolytic adenovirus. Onco Targets Ther 2016; 9:6381-6388.

26. Isnaini I, Permatasari N, Mintaroem K, Prihardina B, Widodo MA. Oxidants-Antioxidants P-rofile in the Breast Cancer Cell Line MCF-7. Asian Pac J Cancer Prev 2018; 19 (11): 3175-3178.

27. Nalkiran I, Turan S, Arikan S, Kahraman OT, Acar L, Yaylim I, et al. Determination of gene expression and serum levels of MnSOD and GPX1 in colorectal cancer. Anticancer Res 2015; 35(1):255-259.

28. Li G, Li X, Wu H, Yang X, Zhang Y, Chen L, et al. CD123 targeting oncolytic adenoviruses suppress acute myeloid leukemia cell proliferation in vitro and in vivo. Blood Cancer J 2014; 4: e194.

29. Konzack A, Jakupovic M, Kubaichuk K, Gorlach A, Dombrowski F, Miinalainen I, et al. Mitochondrial Dysfunction Due to Lack of Manganese Superoxide Dismutase Promotes Hepato-carcinogenesis. Antioxid Redox Signal 2015; 23(14):1059-1075.

30. Ough M, Lewis A, Zhang Y, Hinkhouse MM, Ritchie JM, Oberley LW, et al. Inhibition of cell growth by overexpression of manganese superoxide dismutase (MnSOD) in human pancreatic carcinoma. Free Radic Res 2004; 38(11):1223-1233.

31. Liu XY. Targeting gene-virotherapy of cancer and its prosperity. Cell Res 2006; 16 (11): 879-886.

32. Kirn DH, McCormick F. Replicating viruses as selective cancer therapeutics. Molecular Medicine Today 1996; 2(12):519-527. 
33. Yang Z, von Ballmoos MW, Faessler D, Voelzmann J, Ortmann J, Diehm N, et al. Paracrine factors secreted by endothelial progenitor cells prevent oxidative stress-induced apoptosis ofmature endothelial cells. Atherosclerosis 2010; 211 (1): 103-109.

34. Hu Z, Dong N, Lu D, Jiang X, Xu J, Wu Z, et al. A positive feedback loop between ROS and Mxi1-0 promotes hypoxia-induced VEGF expression in human hepatocellular carcinomacells. Cell Signal 2017; 31:79-86.

35. Kim YM, Kim SJ, Tatsunami R, Yamamura H, Fukai T, Ushio-Fukai M. ROS-induced ROS release orchestrated by Nox4, Nox2, and mitochondria in VEGF signaling and angiogenesis. Am J Physiol Cell Physiol 2017; 312 (6): C749-C764.

36. Konzack A, Kietzmann T. Manganese superoxide dismutase in carcinogenesis: friend or foe? Biochem Soc Trans 2014; 42 (4): 1012-1016.

37. Hamid O, Hoffner B, Gasal E, Hong J, Carvajal RD. Oncolytic immunotherapy: unlocking the potential of viruses to help target cancer. Cancer Immunol Immunother 2017; 66 (10): 1249-1264.

38. Liu C, Sun B, An N, Tan W, Cao L, Luo X, et al. Inhibitory effect of Survivin promoter-regulated oncolytic adenovirus carrying P53 gene against gallbladder cancer. Mol Oncol 2011; 5 (6): 545-554.

39. Martin NT, Bell JC. Oncolytic Virus Combination Therapy: Killing One Bird with Two Stones. Mol Ther 2018; 26 (6): 1414-1422.

40. Lawler SE, Speranza MC, Cho CF, Chiocca EA. Oncolytic Viruses in Cancer Treatment: A Review. JAMA Oncol 2017; 3 (6): 841-849. 
bioRxiv preprint doi: https://doi.org/10.1101/2021.04.08.438934; this version posted April 8, 2021. The copyright holder for this preprint (which was not certified by peer review) is the author/funder, who has granted bioRxiv a license to display the preprint in perpetuity. It is made available under aCC-BY 4.0 International license.

443

444

445

446
41. Taube JM, Galon J, Sholl LM, Rodig SJ, Cottrell TR, Giraldo NA, et al. Implications of the tumor immune microenvironment for staging and therapeutics. Mod Pathol 2018; 31 (2): 214-234. 
Fig 1. construction and identification of Ad-Surp-Transgene. (a) Transgene includes mutants of $m K 5, M n S O D$ with wild-type adenovirus Ad5 as skeleton, $m K 5$ : human plasminogen Kringle5; MnSOD: manganese superoxide dismutase. (b) Correlative identification of three kinds of recombinant oncolytic adenovirus Ad-Surp-empty, Ad-Surp-MnSOD and Ad-Surp-mK5. Channels 7 were negative control, and channels 1,3 and 5 were wild virus identification. The survivin, MnSOD bioRxiv preprint doi: https://doi.org/10.1101/2021.04.08.438934; this version posted April 8, 2021. The copyright holder for this preprint
(which was not certified by peer review) is the author/funder, who has granted bioRxiv a license to display the preprint in perpetuity. It is

and $m K 5$ menes were identified in channels 2, 4 and 6. (c) Western blot analysis showed the protein expression level of $m K 5$ or SOD-2 in HGC-27 cells treated with Ad-Surp-empty, Ad-Surp- $m K 5$ or Ad-Surp-MnSOD, PBS for 48 hours. Data are shown as the mean $\pm \mathrm{SD}$ of three independet experiments. ${ }^{*} \mathrm{P}<0.05,{ }^{*} * \mathrm{P}<0.01$, $* * * \mathrm{P}<0.001$.

a
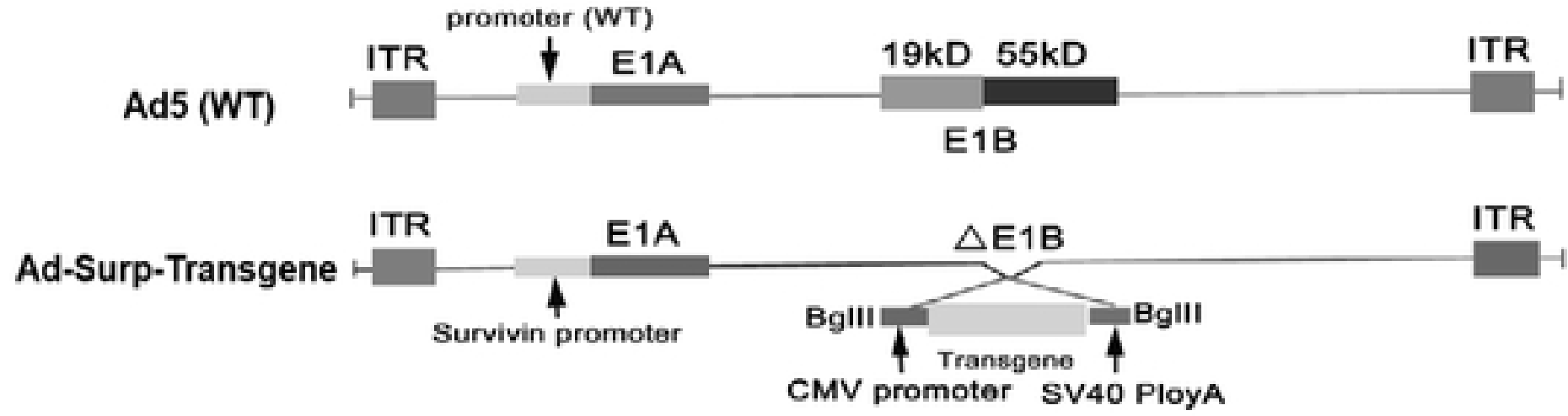

b

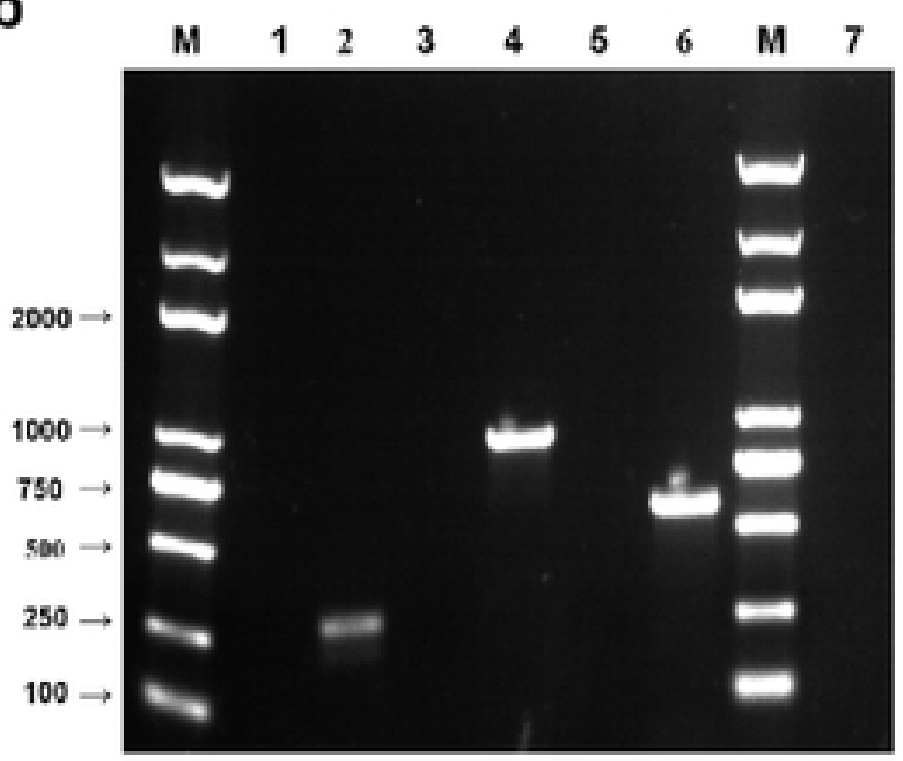

C

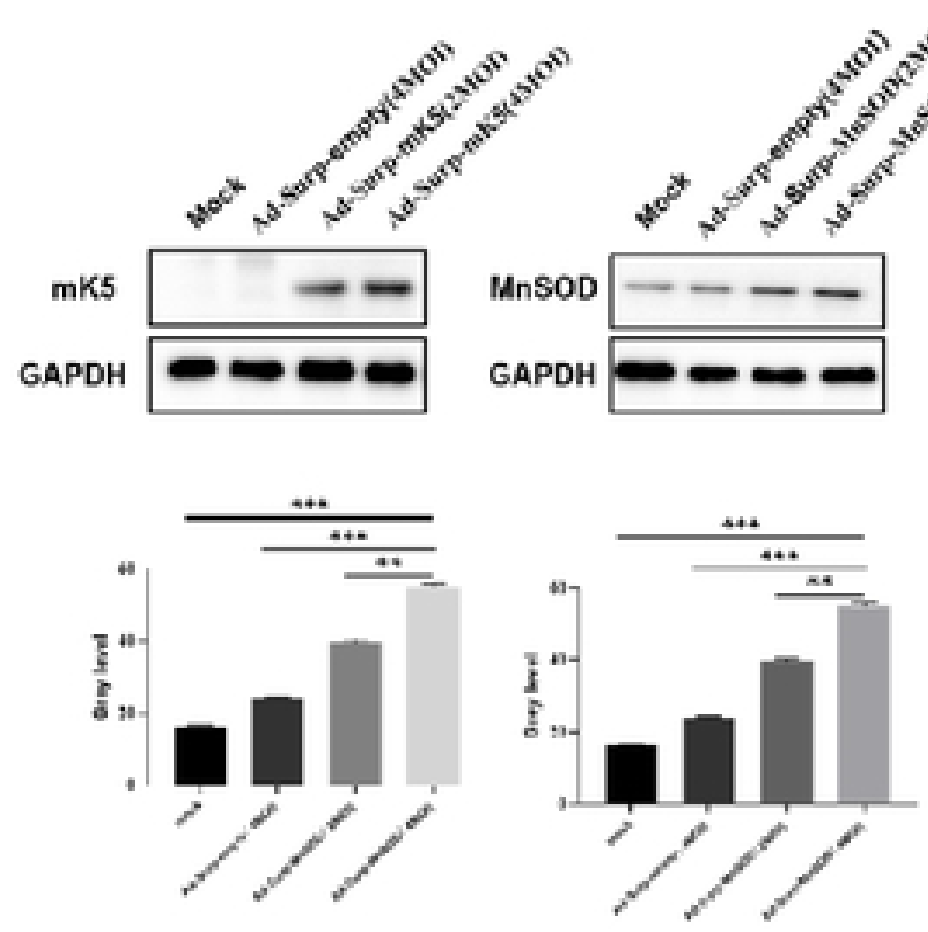


Fig 2. Selective killing effect of recombinant oncolytic adenovirus on gastric cancer. CCK-8 was used to analyze the cell activity of Ad-Surp-Empty, Ad-Surp- $m K 5$, Ad-Surp-MnSOD, Ad-Surp- $m K 5$ and Ad-Surp-MnSOD combined treatment on HGC-27 cells infecte-d with different viruses for $48 \mathrm{~h}(\mathrm{a})$ and $72 \mathrm{~h}(\mathrm{~b})$. The cell viability of NCI-87 cells for $48 \mathrm{~h}(\mathrm{c})$ and $72 \mathrm{~h}(\mathrm{~d})$, AGS cells for $48 \mathrm{~h}(\mathrm{e})$ and $72 \mathrm{~h}$ bioRxiv preprint doi: https://doi.org/10.1101/2021.04.08.438934; this version posted April 8, 2021. The copyright holder for this preprint
(which was not certified by peer review) is the author/funder, who has granted bioRxiv a license to display the preprint in perpetuity. It is

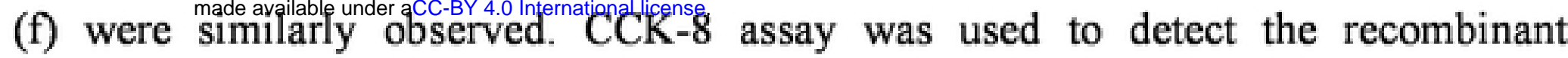
oncolytic adenovirus alone, Ad-Surp- $m K 5$ and Ad-Surp-MnSOD (1:1) combined use had no statistical significance on the cell viability of normal human cells Beas-2B (g) NCM-460 (h) and QSG-7701 (i) cells at 24, 48, 72 and 96h when MOI was 20. The data were shown as mean $\pm \mathrm{SD}$ of three independent experiments. ${ }^{*} \mathrm{P}<0.05,{ }^{* *} \mathrm{P}<$ $0.01,{ }^{* * *} \mathrm{P}<0.001$ 

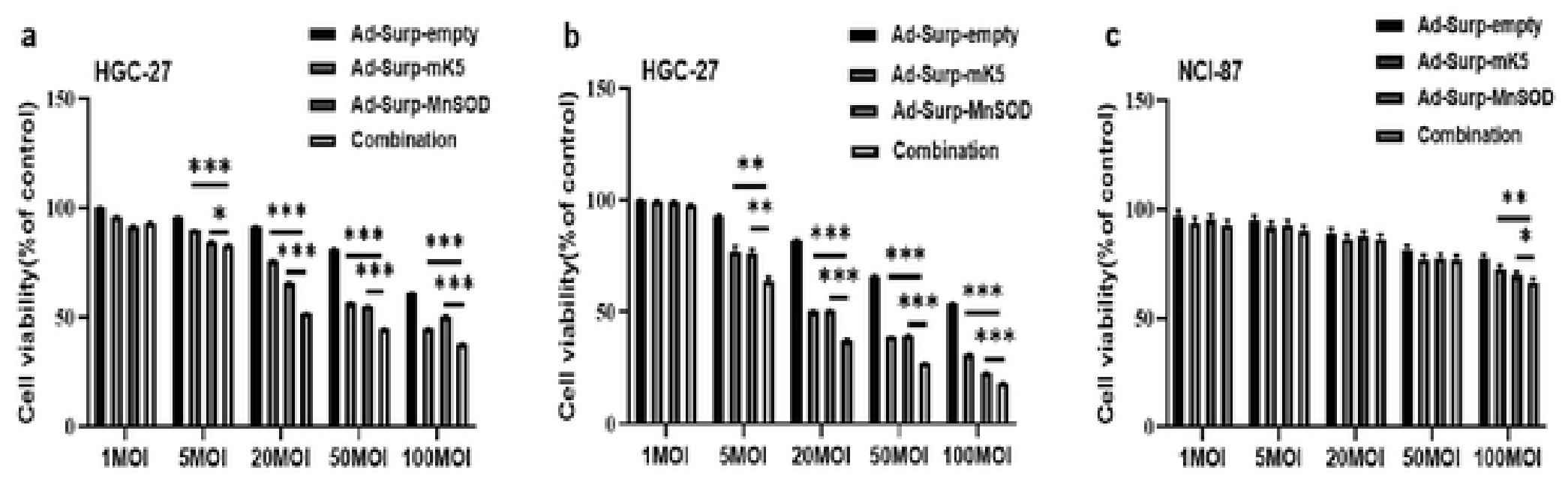

$48 \mathrm{~h}$

$72 \mathrm{~h}$

$48 \mathrm{~h}$

bioRxiv preprint doi: https://doi.org/10.1101/2021.04.08.438934; this version posted April 8, 2021. The copyright holder for this preprint

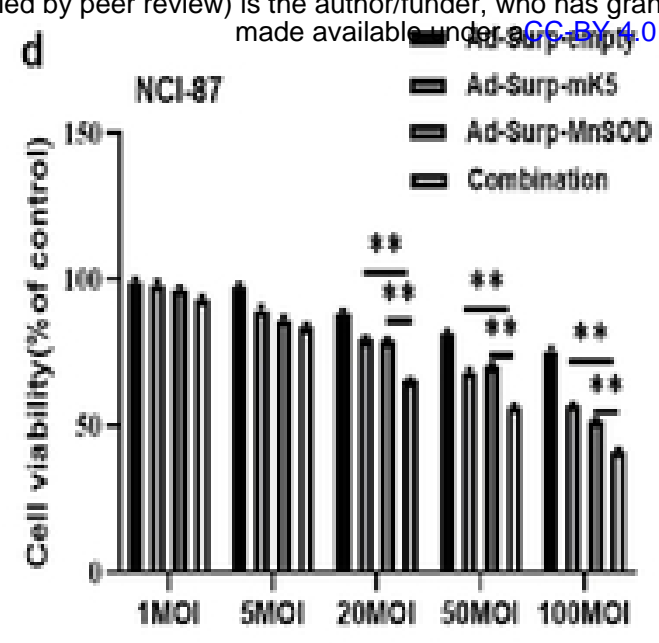

$72 \mathrm{~h}$

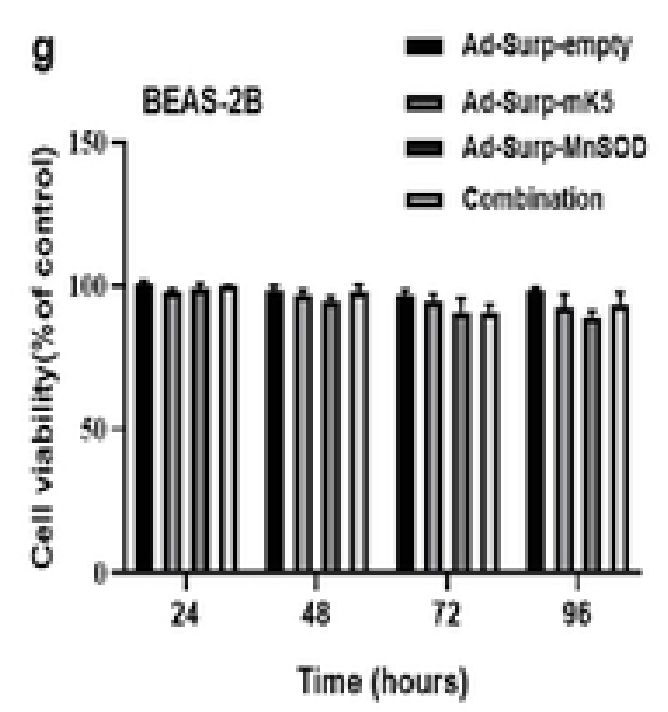

AGS

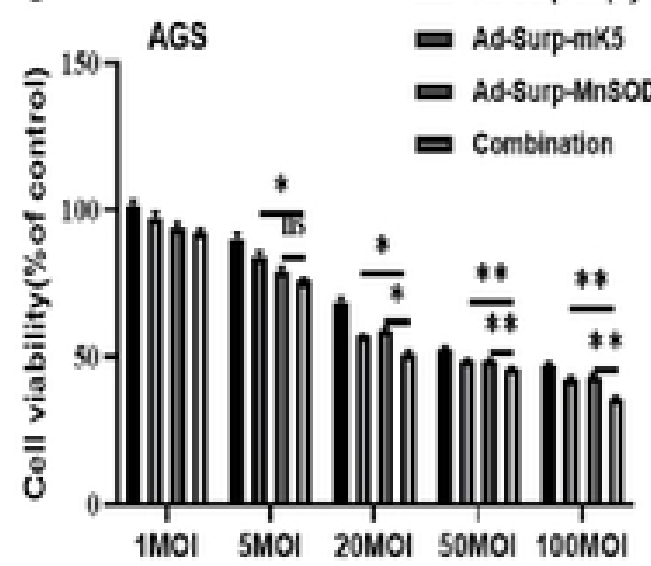

$48 \mathrm{~h}$

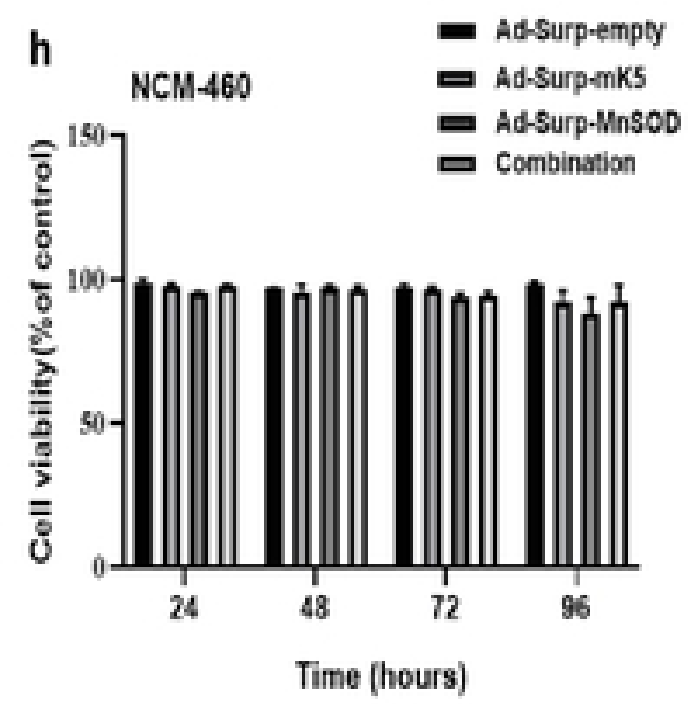

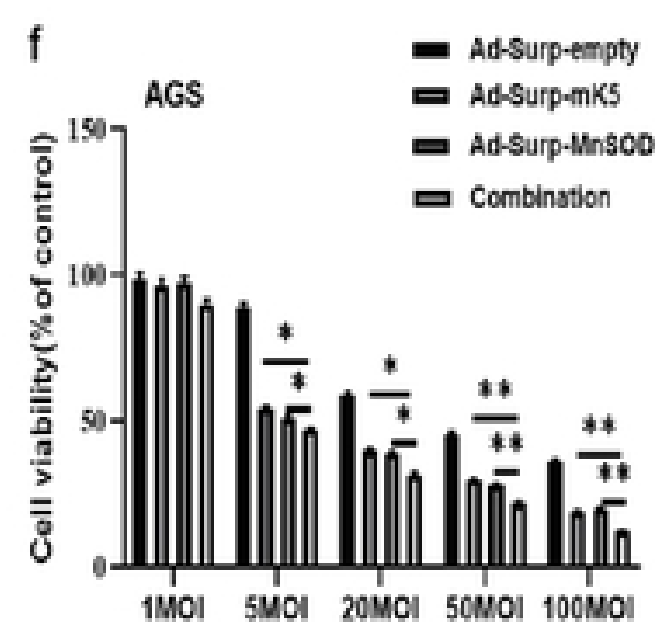

$72 \mathrm{~h}$

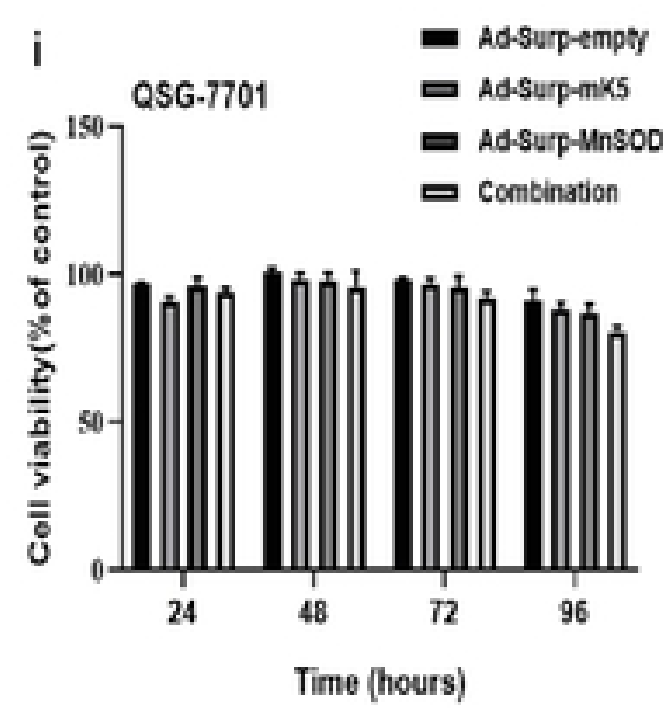


Fig 3. EdU cell proliferation detection. The cell proliferation of Ad-Surp-empty, Ad-Surp- $m K 5, \quad$ Ad-Surp-MnSOD, Ad-Surp-MnSOD and Ad-Surp-mK5 (1:1) combination infected with $\mathrm{HGC}-2748 \mathrm{~h}$ was observed under fluorescence microscope (MOI=5, Blue fluorescence, Hoechst33342 staining; Red fluorescence, Apollo staining, scale bar $=20 \mathrm{um}$ ). The data were shown as mean $\pm \mathrm{SD}$ of three independent experiments. * $\mathrm{P}<0.05, * * \mathrm{P}<0.01, * * * \mathrm{P}<0.001$. bioRxiv preprint doi: https://doi.org/10.1101/2021.04.08.438934; this version posted April 8, 2021. The copyright holder for this preprint
(which was not certified by peer review) is the author/funder, who has granted bioRxiv a license to display the preprint in perpetuity. It is

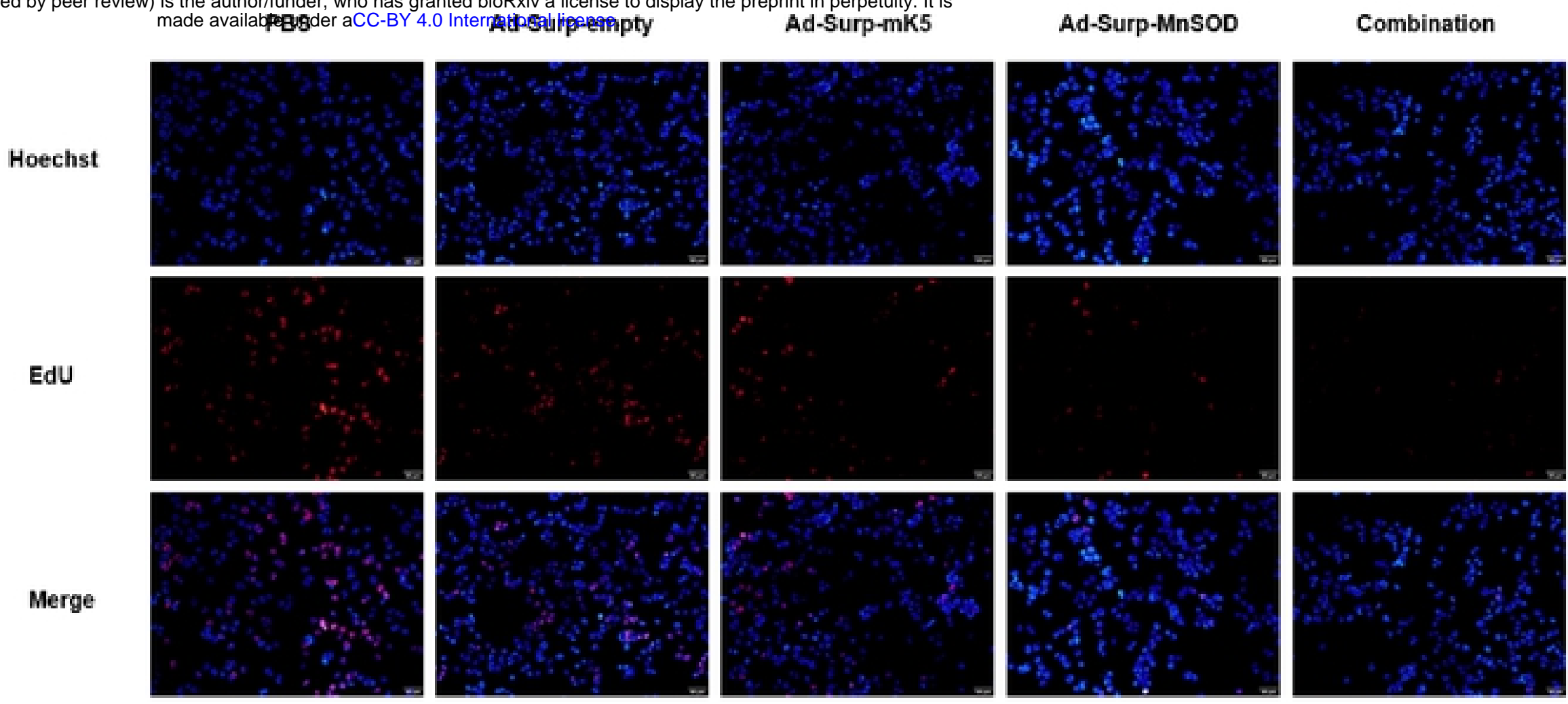


Fig 4. Various recombinant oncolytic adenoviruses selectively induce apoptosis and the mechanism of action . (a-j) HGC-27 (upper two rows) and QSG-7701 (lower two rows) cells were infected with $(\mathrm{a}, \mathrm{f})$ phosphate (PBS) $(\mathrm{b}, \mathrm{g})$ Ad-Surp-empty $(\mathrm{c}, \mathrm{h})$ Ad-Surp-mK5 (d,i) Ad-Surp-MnSOD (e,j) Ad-Surp-mK5 and Ad-Surp-MnSOD ombination (1:1) for $48 \mathrm{~h}(\mathrm{MOI}=5)$, cell apoptosis was detected by Hoechst33342 staining. Chromatin karyokinization (indicated by arrow) was observed under bioRxiv preprint doi: https://doi.org/10.1101/2021.04.08.438934; this version posted April 8, 2021. The copyright holder for this preprint
(which was not certified by peer review) is the author/funder, who has granted bioRxiv a license to display the preprint in perpetuity. It is

fluorescence microscope, scale bar= $20 \mathrm{um}$. (k) In figure a-j, HGC-27 and QSG-7701 cells are stained by Hoechst 33342 , and the number of apoptotic cells is observed under fluorescence microscopy. (1-m) HGC-27 cells were treated with different recombinant oncolytic adenovirus $48 \mathrm{~h}$, and the PBS treatment group was the control group (MOI=5). The data were shown as mean $\pm \mathrm{SD}$ of three independent experiments.

$* \mathrm{P}<0.05, * * \mathrm{P}<0.01, * * * \mathrm{P}<0.001$. 

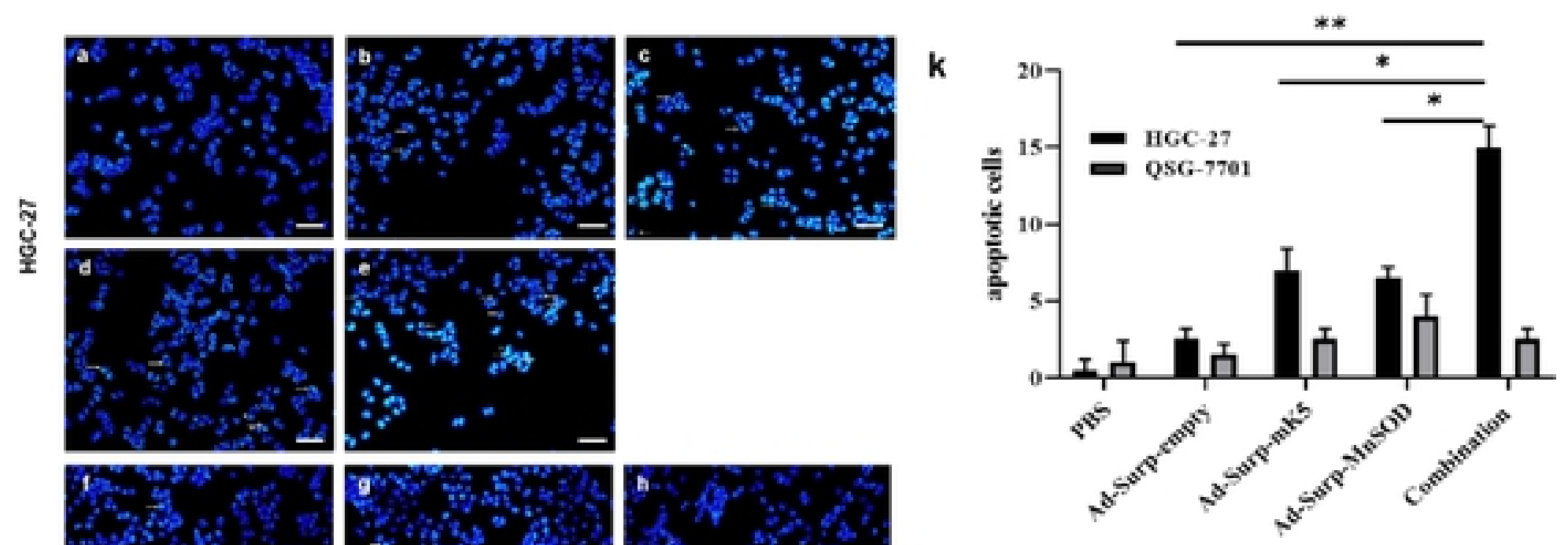

(which was not certified by go
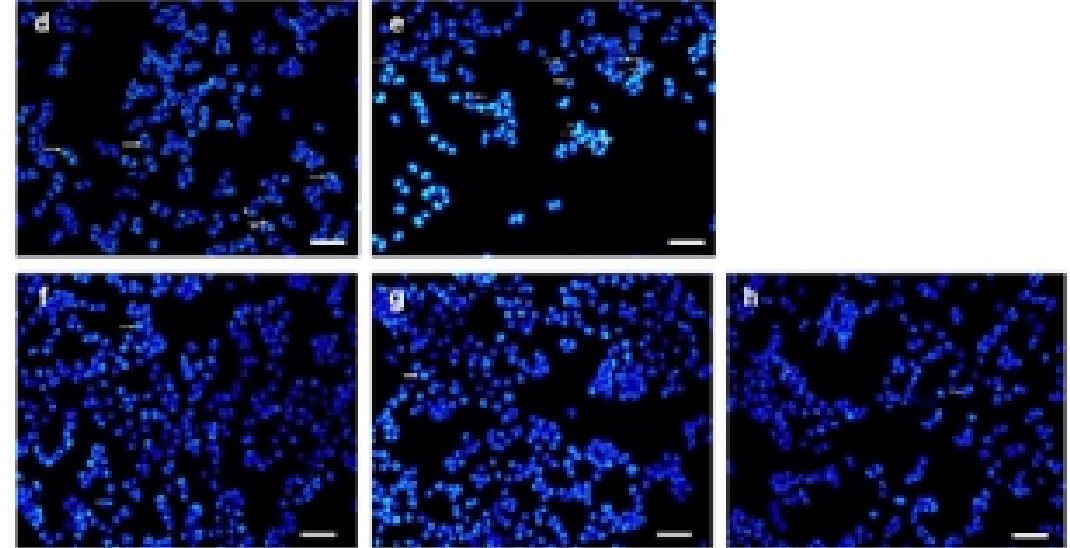

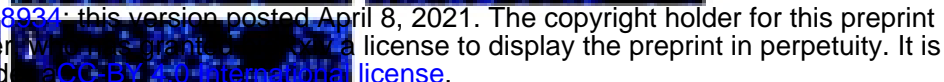
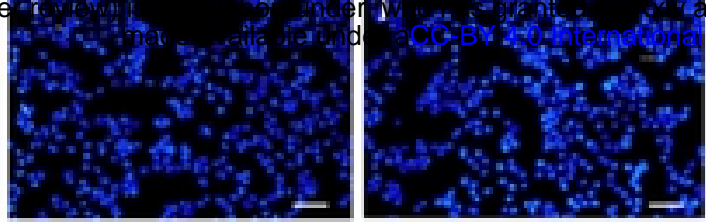
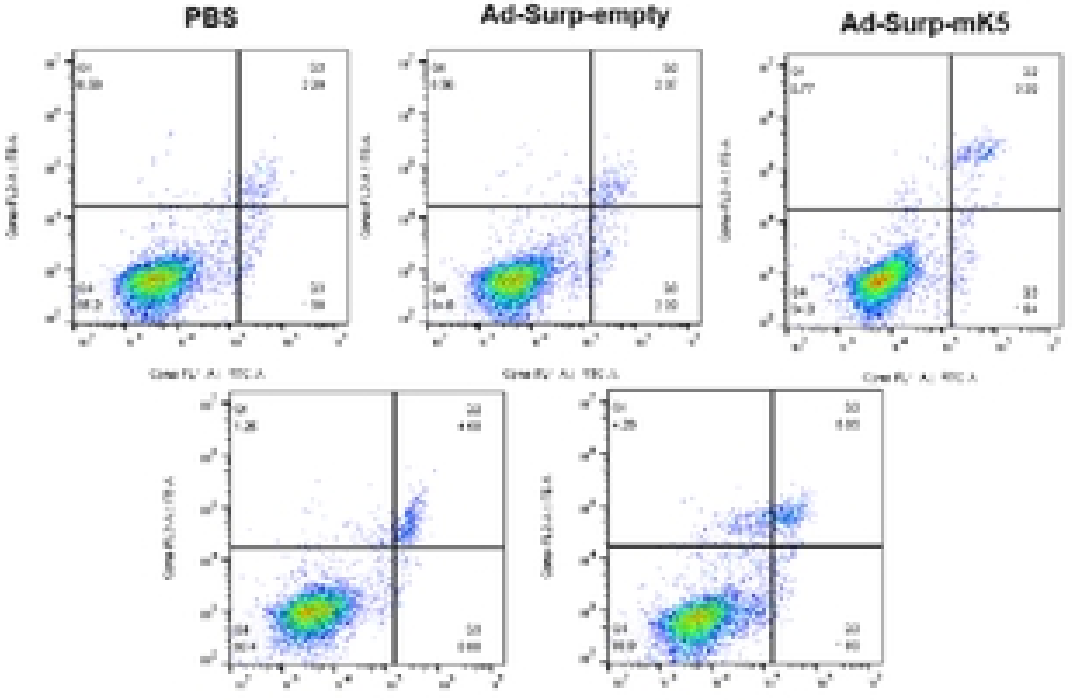

Ad-Surp.Mnsod

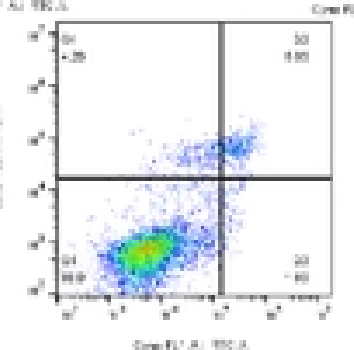

Combination m

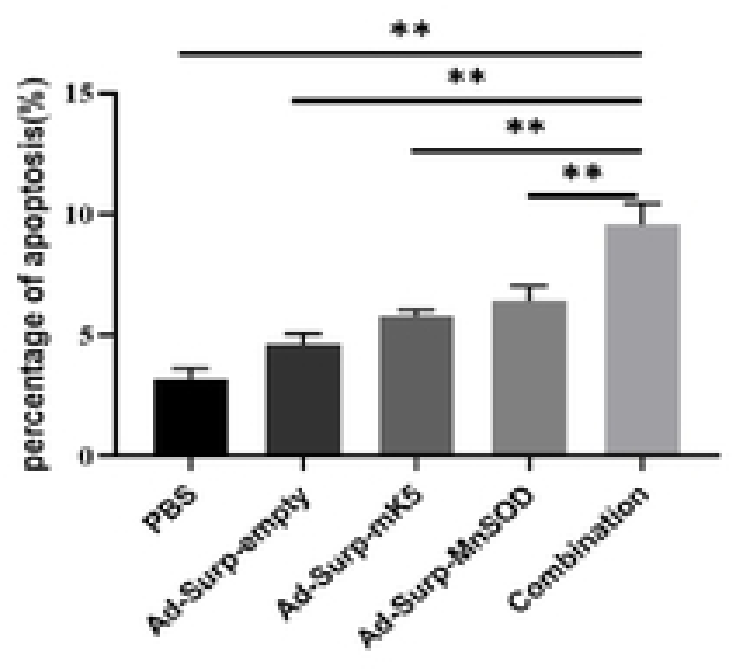


Fig 5. Detection of protein expressions associated with virus proliferation and apoptosisby western blot. As described above, expression of caspase-3, caspase- 9 , caspase-8, PARP, cleaved-PARP, apoptotic proteins $\mathrm{Bcl}-2, \mathrm{Bax}$ and virus proliferation-associated protein E1A was observed after treatment with $\mathrm{HGC}-27$ by different viruses.

bioRxiv preprint doi: https://doi.org/10.1101/2021.04.08.438934; this version posted April 8, 2021. The copyright holder for this preprint (which was not certified by peer review) is the author/funder, who has granted bioRxiv a license
made available under aCC-BY 4.0 International license.

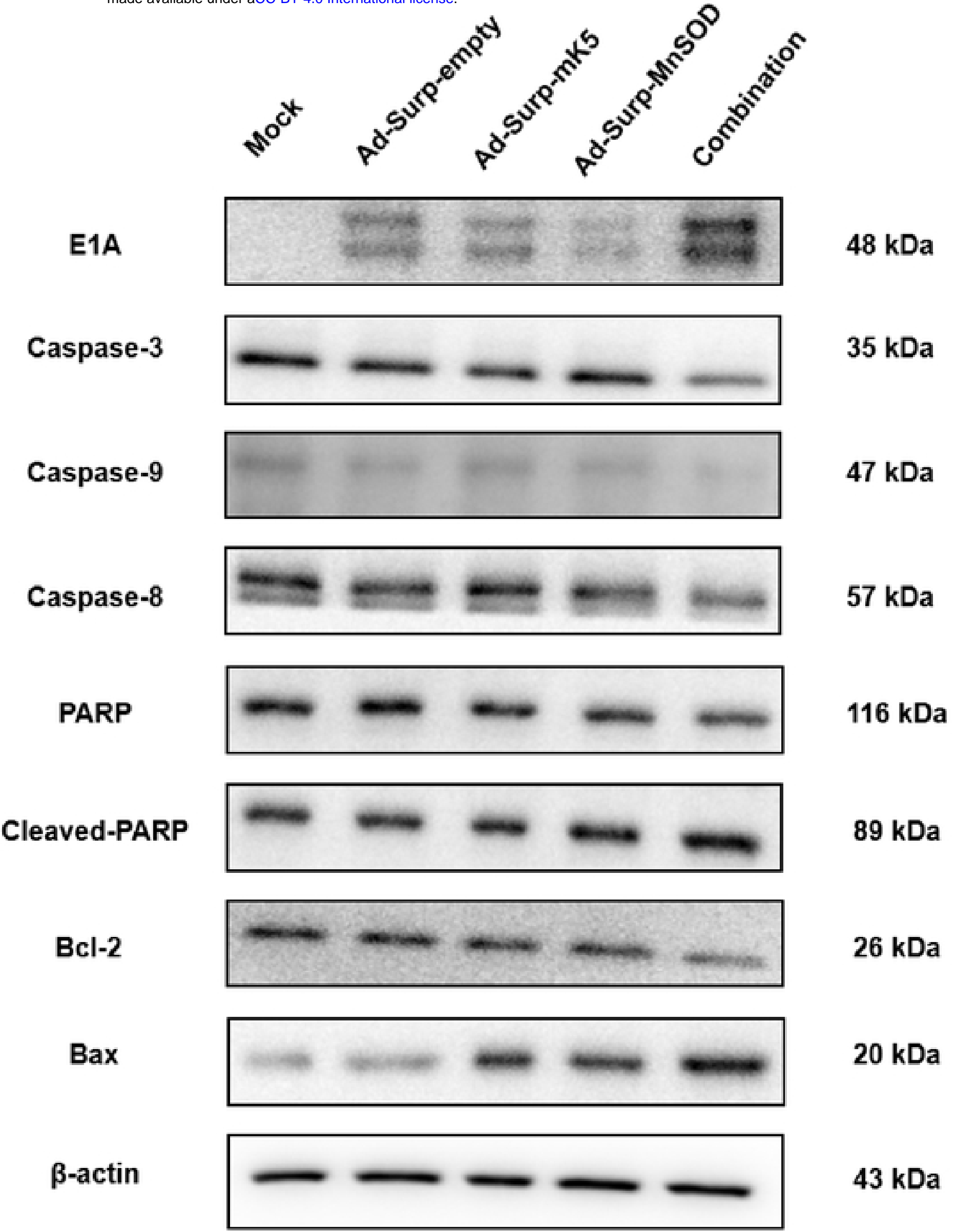


Fig. 6 In vivo antitumor effect of recombinant oncolytic adenoviru. HGC-27 cells $\left(1 \times 10^{6}\right)$ were subcutaneously injected into female BALB/c nude mice to establish a mouse tumor xenograft models. (a) When the tumor grew to $80-100 \mathrm{~mm}^{3}$, the nude mice were randomly divided into 5 groups $(n=5)$. The mice were injected with different adenovirus $1.0 \times 10^{8} \mathrm{PFU} /$ mouse every other day for 3 consecutive intratumor bioRxiv preprint doi: https://doi.org/10.1101/2021.04.08.438934; this version posted April 8, 2021. The copyright holder for this preprint
(which was not certified by peer review) is the author/funder, who has granted bioRxiv a license to display the preprint in perpetuity. It is
made available under aCC-BY 4 . International license

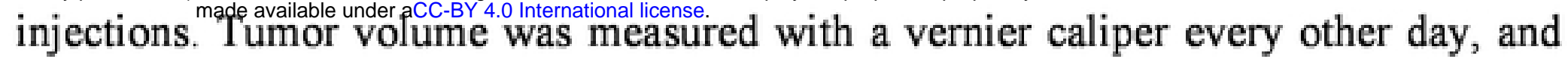
the experiment was stopped on the 18 th day. (b) Photographs of anatomical tumors of nude mice treated with different adenoviruses. (c) Tumor growth trend of mice Tumor: Volume $\left(\mathrm{mm}^{3}\right)=\left(\right.$ Length $\left.\times W i d t h^{2}\right) / 2$. (d) Changes in body weight of mice in each group during the experiment showed no statistical significance among each group. (e) The final body weight of nude mice was measured by tumor resection after the end of the experiment, and there was no statistical significance among all groups. (f) The final mass of tumors in each group at the end of the experiment. The data were shown as mean $\pm \mathrm{SD}$ of three independent experiments. $* \mathrm{P}<0.05$, ** $\mathrm{P}<$ $0.01, * * * \mathrm{P}<0.001$ 
a

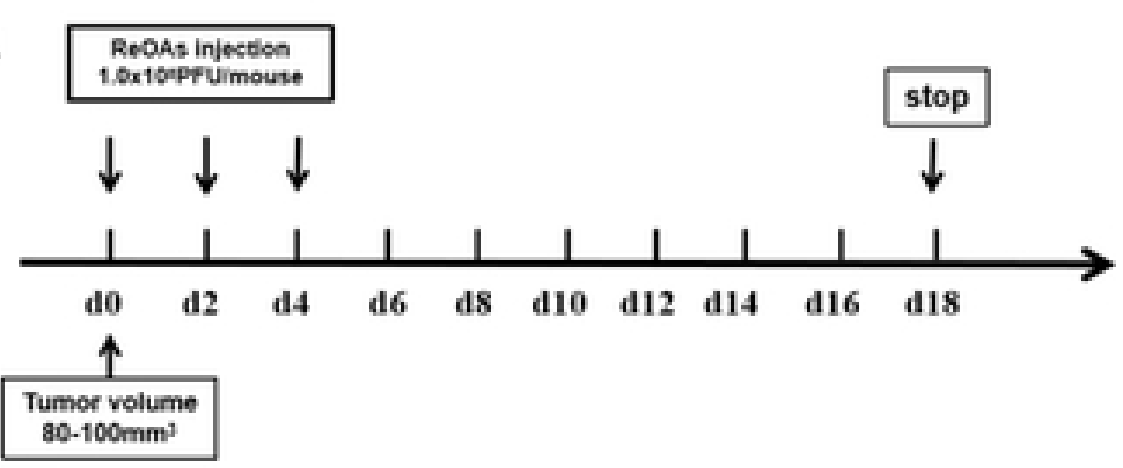

b

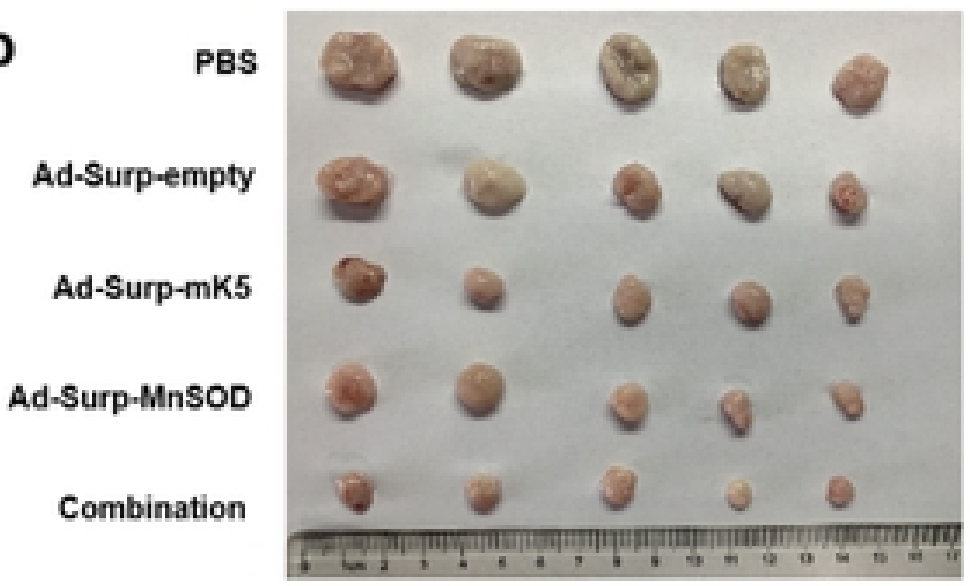

C

$$
\left.{ }^{2500}\right] \rightarrow \text { PBS }
$$

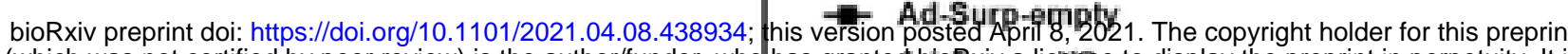

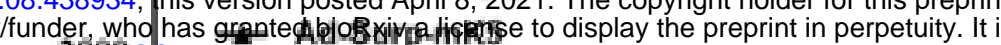

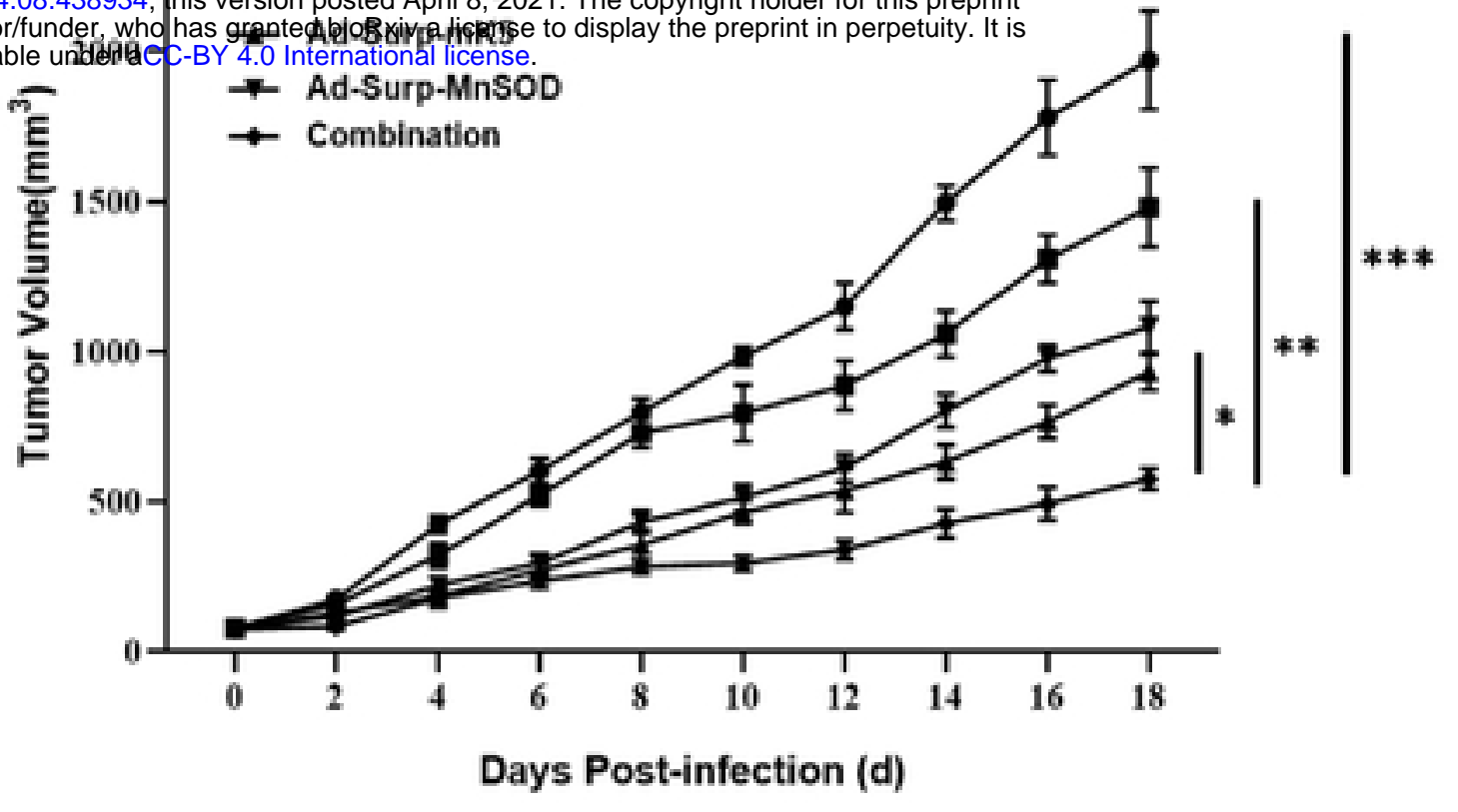

d

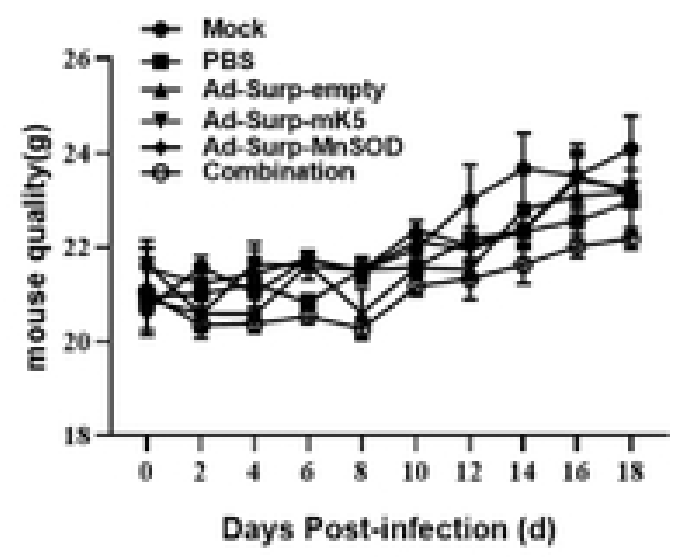

e

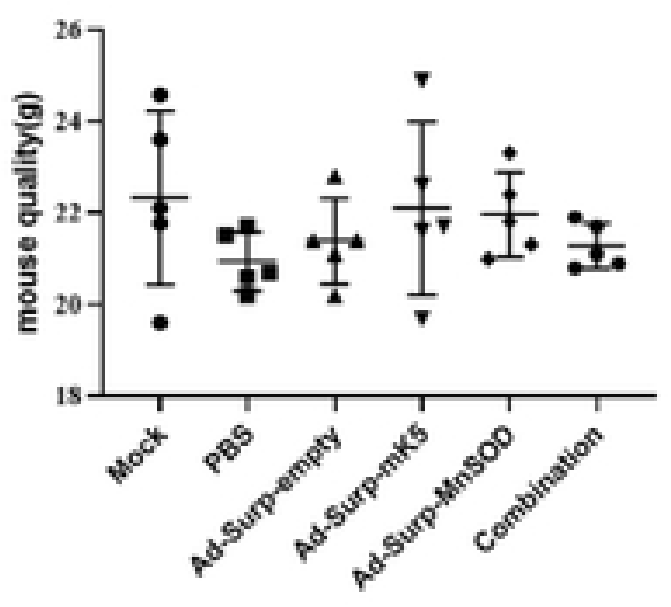

f

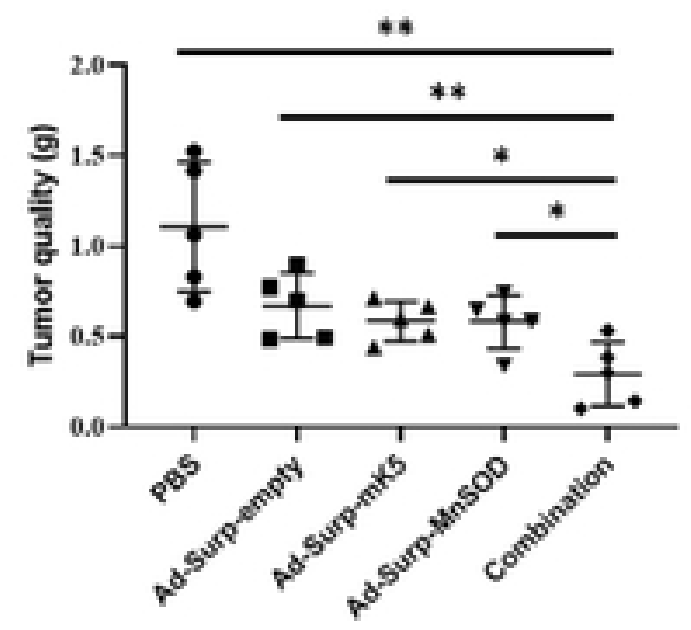


Fig 7. Detection of apoptosis rate of tissue cells by TUNEL staining. (a) Tumor fixation, embedding and cryopreservation were performed after tumor dissection in nude mice, and the thickness of frozen tissue sections was $6 \mathrm{~nm}$ (blue fluorescence, DAPI staining; Red fluorescence, TUNEL positive staining), scale bar=200 um. (b) Statistical analysis of positive cells detected by TUNEL staining. The data were shown as mean $\pm \mathrm{SD}$ of three independent experiments. $* \mathrm{P}<0.05, * * \mathrm{P}<0.01, * * * \mathrm{P}<0.001$. bioRxiv preprint doi: https://doi.org/10.1101/2021.04.08.438934; this version posted April 8, 2021. The copyright holder for this preprint
(which was not certified by peer review) is the author/funder, who has granted bioRxiv a license to display the preprint in perpetuity. It is

a

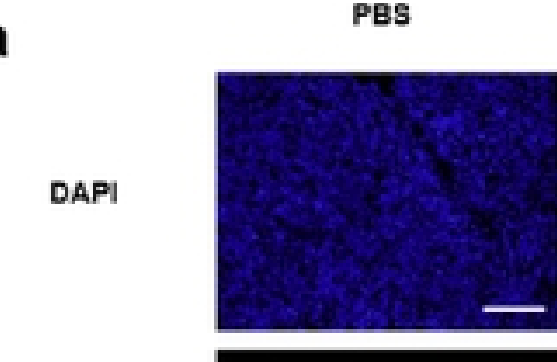

TUNEL

Merge
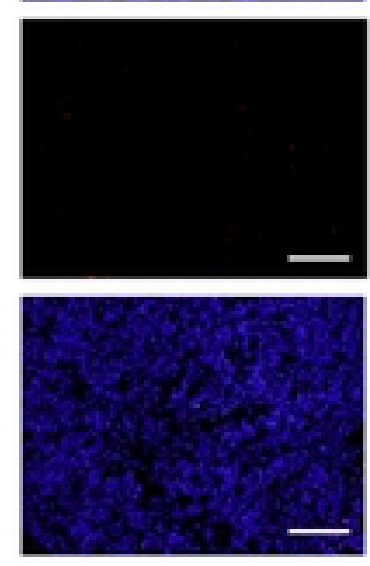

Ad-Surp-empty
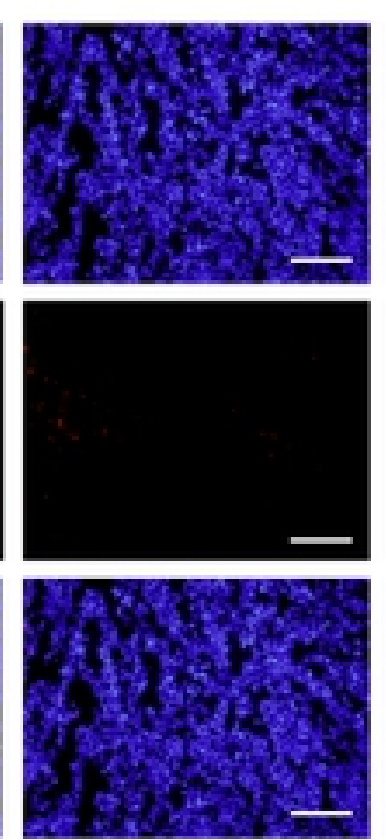

Ad-Surp-mK5
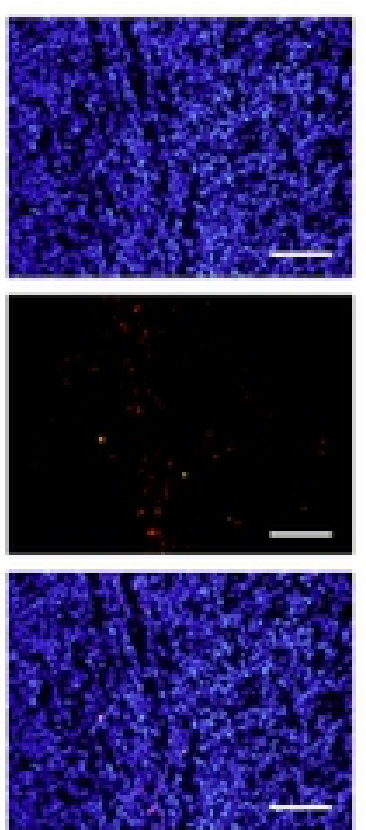

Ad-Surp-Mnsoo
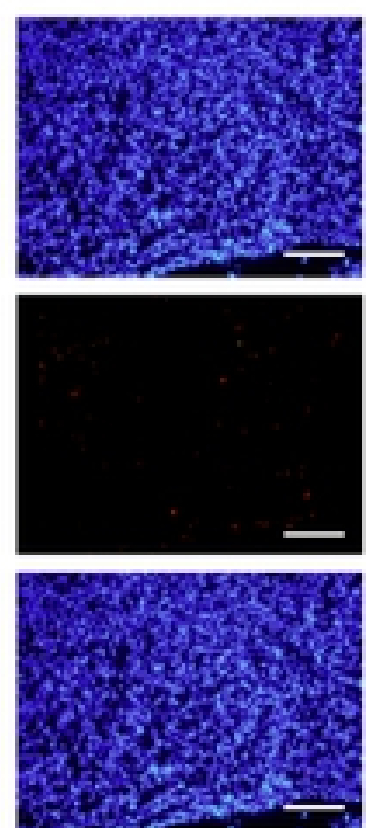

Combination
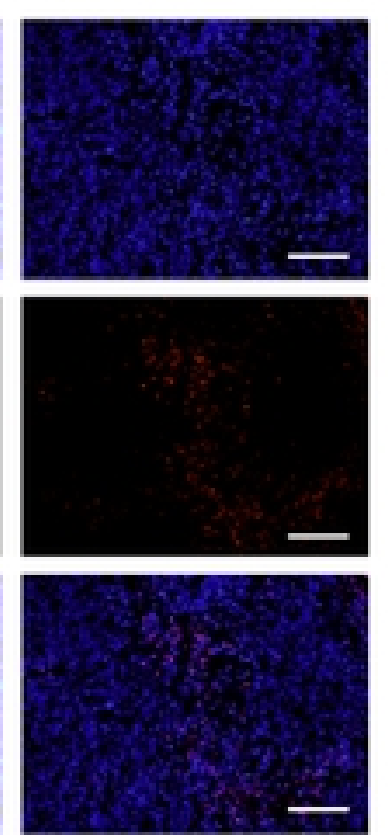

b

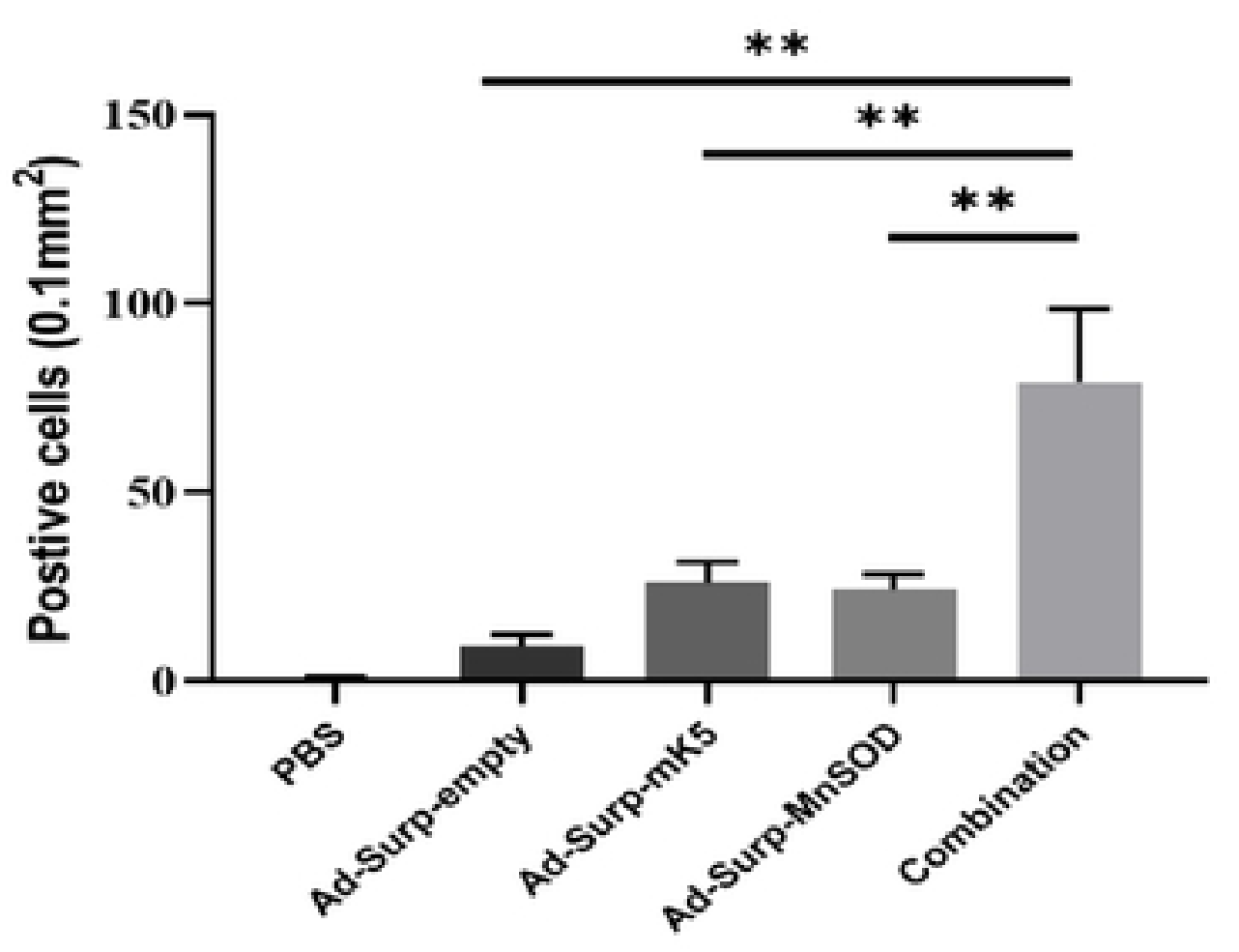

